\title{
DEVELOPMENT OF ELDERLY QUALITY OF LIFE INDEX- EQOLI: THEORETICAL-CONCEPTUAL FRAMEWORK, CHOSEN METHODOLOGY, AND RELEVANT ITEMS GENERATION
}

\author{
Sergio Márcio Pacheco Paschoal, Wilson Jacob Filho, Julio Litvoc
}

Paschoal SMP, Jacob Filho W, Litvoc J. Development of an Elderly Quality of Life Index- EQoLI: Theoretical-conceptual framework, chosen methodology, and relevant items generation. Clinics. 2007;62(3):279-88.

PURPOSE: To describe the initial steps of the construction process of a quality of life evaluation instrument for the elderly-the theoretic-conceptual framework for the construct, Quality of Life in Old Age; the construction methodology; and the generation of relevant items.

METHODS: The first step was to conceptualize and define the construct, determining how much the elderly are able to perform of what they believe to be important in their lives and whether they are satisfied with what was possible to perform. The next step was to select and describe the construction methodology (the Clinical Impact Method) and the phase of generation of relevant items for the research object. The necessary procedures were delineated through a pilot study, which helped to establish all phases of the used methodology. The viability of the construction of the Quality of Life in Old Age evaluation instrument was demonstrated along with the needed adaptations.

RESULTS: From 1032 answers by older people, 138 relevant items for the construct were identified by the items generation process. The pilot study demonstrated the suitability of the application of the methodology and established modifications to the preliminary items list, resulting in a new 139-item list.

DISCUSSION: Now that the theoretical-conceptual framework of the construct as well as the construction methodology and the items generation are established, the next step will consist of administering the resulting list to a sample of elderly people for item reduction and distribution of items into dimensions.

KEYWORDS: Elderly. Quality of life. Questionnaires. Evaluation. Health impacts.

\section{INTRODUCTION}

\section{Quality of Life in Old Age}

The evaluation of the quality of life in the elderly has become extremely important due to the longevity brought to human life. Living longer may result in a life marked with dependence and disabilities. The epidemiologic

Department Preventive Medicine- University Medical School - São Paulo/ SP, Brazil.

Email: spaschoal@gmail.com

Received for publication on August 30, 2006.

Accepted for publication on February 07, 2007. changes resulting from this demographic transition have led to a greater prevalence of chronic degenerative conditions, with sequelae and complications, producing impairments, dependence, and the need for long-term care.

The aging process is heterogeneous, frequently leading to 2 extreme situations, ie, an excellent quality of life or a very bad quality of life; many intermediate possibilities can be found between these extremes. The various human life dimensions and the way each person lives, according to different patterns, rules, expectations, desires, values, and principles, require multidimensional measurement instruments that are sensitive to the great variability of the elderly population. These instruments must consider the specific char- 
acteristics of this age group, which are different from those of the young because of their values and experiences. Furthermore, age-related factors affect health, a very important dimension of the quality of life in the elderly. ${ }^{1-4}$ Moreover, in this stage of life, various conditions, such as retirement, widowhood, loss of social roles, social support network reduction, loneliness, and lack of personal life significance, can create obstacles to a better quality of life.

For a chronic disease bearer, cure may not be the main purpose so much as the maintenance of a good quality of life. For health professionals, the measurement of quality of life is a vital component for assessing the effect of their treatments and interventions. However, quality of life is a concept that is vague and difficult to quantify, and quality of life scales have seldom been used to measure results or to check the efficacy of interventions. ${ }^{5}$

In health care, especially in the developed countries, quality of life evaluations have become usual in research; action, service, and policy planning; resource allocation; program evaluation, with an exponential growth of publications $^{6}$. Since the 1970s, there has been an explosion of interest about this subject. Research about quality of life among the elderly has gained importance since 1977, when the descriptor "quality of life" was first used in PubMed. The elderly, comprising less than one-fifth of the world population, are responsible for more than $40 \%$ of the research concerning quality of life (Table 1). In Brazil, the recognition of importance of quality of life research is more recent, and is gaining popularity.

In Latin America and the Caribbean Islands, the first reference to the construct, quality of life in old age, appeared in 1987 in a study about health problems of Chilean elderly ${ }^{8}$, which described mortality and hospital discharges during 1 year, emphasizing the importance of a good functional capacity in performing daily activities to improve the quality of life. This was a study where quality of life was not the object of study, playing only a secondary role. Since then, not much has been published, 1999 being the year with the greatest number of papers (17 references). ${ }^{7}$ From 1985 to 2003 , only $116(8.4 \%)$ references, of a total of 1381 regarding quality of life, dealt with quality of life in old age. Among these, only 13 used quality of life evaluation instruments, which were translated from generic instruments, ie, not constructed taking our own cultural context into account; 11 of these had quality of life as the main object of the study, and none constructed any

Table 1 - Yearly number of references found in PubMed, using "quality of life" $[\mathrm{MeSH}]$ and "aged" $[\mathrm{MeSH}]$ descriptors $(1997-2000)$

\begin{tabular}{|c|c|c|c|}
\hline Year & "Quality of Life" & "Quality of Life" and "Aged" & $\% *$ \\
\hline 1977 & 177 & 51 & 28,81 \\
\hline 1978 & 240 & 69 & 28,75 \\
\hline 1979 & 271 & 94 & 34,69 \\
\hline 1980 & 253 & 89 & 35,18 \\
\hline 1981 & 268 & 69 & 25,75 \\
\hline 1982 & 316 & 117 & 37,03 \\
\hline 1983 & 330 & 133 & 40,30 \\
\hline 1984 & 349 & 113 & 32,38 \\
\hline 1985 & 400 & 133 & 33,25 \\
\hline 1986 & 491 & 161 & 32,79 \\
\hline 1987 & 564 & 179 & 31,74 \\
\hline 1988 & 589 & 200 & 33,96 \\
\hline 1989 & 887 & 280 & 31,57 \\
\hline 1990 & 1001 & 306 & 30,57 \\
\hline 1991 & 1077 & 319 & 29,62 \\
\hline 1992 & 1255 & 402 & 32,03 \\
\hline 1993 & 1451 & 510 & 35,15 \\
\hline 1994 & 1593 & 555 & 34,84 \\
\hline 1995 & 1904 & 737 & 38,71 \\
\hline 1996 & 2150 & 840 & 39,07 \\
\hline 1997 & 2369 & 929 & 39,21 \\
\hline 1998 & 2655 & 1056 & 39,77 \\
\hline 1999 & 3019 & 1211 & 40,11 \\
\hline 2000 & 3264 & 1278 & 39,15 \\
\hline 2001 & 3784 & 1569 & 41,56 \\
\hline 2002 & 4025 & 1743 & 43,30 \\
\hline 2003 & 4662 & 2664 & 57,14 \\
\hline Total & 39.344 & 15.807 & 40,18 \\
\hline
\end{tabular}

Source - PubMe. $(*)$ - percentage of references regarding quality of life in the elderly relative to the total number of references regarding quality of life, per year 
measurement instrument or scale. A plausible explanation for this situation may be that in the less developed countries, aging is a more recent process. The demographic transition in these countries occurred in the last half of the 20th century, when the evidence of the rapidly increasing aging of their population forced them to change their "young country" paradigm. It was only then that research about the consequences of aging began to be valued and quality of life in the elderly became an important subject of study.

Despite the great number of instruments in the literature, very few have been developed with the elderly population in mind. Tipically, universal instruments, constructed and validated for other age groups and used indiscriminately for any age group, have been employed to evaluate the elderly.

Since 1995, our group has been developing an evaluation instrument to measure the quality of life in old age. The small number of instruments designed for this population in the global literature and its inexistence in our country led us to propose the construction of an instrument for the elderly within our socioeconomic-cultural context.

\section{Strategies for instrument construction}

Two strategies are generally used in the development of multi-item scales, the clinimetric and the psychometric. $^{12,13}$ The first one, used in clinical medicine, relies on the diverse judgments of patients, clinicians, and other health professionals concerning the clinical phenomena that comprise several characteristics and attributes of the patients. The psychometric strategy used in psychology and intelligence tests relies on mathematical techniques to develop a scale that measures the subject's characteristics or attributes.

In both strategies, instrument development consists of 3 stages: item generation, item reduction, and item distribution into dimensions, their difference occurring in the last 2 stages (item reduction and item distribution), each strategy developing different forms to reach the final instrument.

Item generation defines the content of the instrument and ensures that all the important variables are considered. Different items and dimensions that delineate the phenomenon are created from a conceptual framework of the object to be measured, defining the content of the scale and ensuring the inclusion of the important topics. Item reduction eliminates redundant or inappropriate items and decreases the number of items to a total that is feasible to administer while ensuring that the scale measures the construct or clinical phenomenon of interest. Finally, the selected items must be grouped into dimensions.

This article describes 3 fundamental steps in the con- struction process of quality of life evaluation instrument: the theoretical-conceptual framework of the Quality of Life in Old Age construct, the methodology used for the questionnaire construction, and the generation of relevant items. This last step was implemented in 2 different periods: In the first one, from 1996 to 1998, 86 patients from the Group for Multidisciplinary Attendance to the Elderly (Grupo de Atendimento Multidisciplinar ao Idoso Ambulatorial GAMIA) were interviewed; different determinants of good and bad quality of life in old age, which constituted the items, were targeted. In the second period, from December of 1999 to March of 2000, a pilot study was conducted with 19 elderly patients of the Geriatric Ambulatory of the Geriatric Service of Hospital das Clínicas da Faculdade de Medicina da Universidade de São Paulo to verify the adaptation of the chosen methodology and the appropriateness of the initial pool of items. ${ }^{7}$

\section{METHODS}

\section{Theoretical-conceptual framework of the Quality of Life in Old Age construct}

The aging process is influenced by various factors, such as genetic constitution, gender, character, personality, habits and life style, socioeconomic conditions, functional status, environment, individual values and beliefs, manners, way of seeing life, and spirituality.

Conceptualizing and defining the object of measurement is the first step to consistency of any projected instrument. It is necessary to choose which life aspects will be evaluated and which dimensions will comprise the construct. Thus, an instrument is constructed from assumptions based on a theoretical-conceptual framework of the study object.

Our object of measurement was the quality of life in old age construct. The following strategy was chosen: determining how much of what the elderly want is actually achieved by them; ascertaining whether this corresponds to the degree of satisfaction/dissatisfaction they feel with their lives; evaluating whether their expectations were fulfilled, their needs satisfied, and to what extent this was done. The construct value or its score would be the difference between these expectations and their actual accomplishment, i.e., between desires and needs and their fulfillment. A 3-part instrument was proposed: the first part investigates whether the elderly are satisfied/dissatisfied with their lives, followed by 2 correlated parts, first where they say how they value some aspects of life and then what they have accomplished in these aspects, allowing for the possibility of comparison. We addressed how much was 
fulfilled of what the elderly consider important in their lives, leaving for a later stage the comparison of degree of satisfaction/dissatisfaction to fulfillment or not of their proposed objectives and expectations. ${ }^{11-13}$

Our goal was to measure how much of what the elderly idealize as important for a good or bad quality of life they are actually achieving, how much of what they long for has become reality, how much of what they reject they have had to live with, and whether they are satisfied with what has been possible to fulfill and achieve. Therefore, the conception is completed with the previous evaluation of their level of satisfaction/dissatisfaction, and the investigator can later verify the agreement between the satisfaction/dissatisfaction level and the expectations fulfilled. The greater the distance between what the elderly idealize and what has actually been achieved, the worse their quality of life and vice versa. Each elderly patient will be evaluated according to his values, rules, beliefs, patterns, interests, and expectations, which can change over time.

Another important theoretical decision was to favor the elderly perception concerning the quality of their life, i.e., they should also influence the choice of the items included in the instrument.

Having in mind this conceptualization and how the Quality of Life in Old Age construct could be operationalized, we compose the following definition of quality of life:

"Quality of life is a person's perception of well-being that derives from the evaluation of how much has been accomplished of what was idealized as important for a good life and from the degree of satisfaction with what has been possible to accomplish up to that moment."

Our ultimate objective is to design an evaluation instrument of the quality of life in the elderly (aged 60 years and more) of both genders, with the purpose of monitoring the longitudinal change in the quality of life as well as of evaluating the impact of conducts, interventions, and treatments on it. Therefore, this instrument must be both discriminative (to detect differences between subjects at a single point in time) and evaluative (to detect longitudinal change within subjects). It must also be multidimensional, comprising dimensions and items identified by the elderly as relevant to their quality of life. Moreover, in the item generation phase, it is necessary to ensure that all important variables identified by the elderly are considered for possible inclusion in the instrument. Because of the low schooling level of many Brazilian elderly, face-to-face interview was the elected application method for the evaluation instrument, with the interviewer reading and instructing, without interfering. The instrument application must be easy for the patient as well as the interviewer, its accuracy must be evaluated, and its reliability and validity tested before being used on large scale.

\section{Construction methodology}

The second step of the instrument development is the choice of the construction methodology.

Our study elected the clinimetric strategy, applying the clinical impact method, ${ }^{14-16}$ based mainly on values, perceptions, and judgments of the target population and its health professionals. Evaluating patients with chronic obstructive pulmonary disease, ${ }^{14-16}$ the authors of the method established the impact that chronic airflow limitation brought to the quality of life of patients with this illness. In our study, the construction of a generic instrument to assess the quality of life in the elderly required an adjustment of the methodology used in the construction of the disease-specific quality of life evaluation instruments ${ }^{17-20}$ in the construction of the instrument for fragile elderly, ${ }^{21}$ and in the search for the impact factors for evaluating the quality of life of women with osteoporosis. ${ }^{22}$

According to Guyatt et al, ${ }^{15}$ the number of subjects that identifies the item as relevant (frequency), the importance attributed to it, and its responsiveness (ability to detect alteration, if this should occur) are important criteria for retaining this item in the construction of evaluation instruments. The key issue for frequency and importance criteria is the way they should be combined. Although some investigators favor more sophisticated approaches, such as factor analysis, or analysis of the main component, a simple and reasonable approach is to multiply the frequency of each item by its mean importance. The items with the greatest products of frequency and mean importance should be retained.

A brief review of the study of Guyatt et a ${ }^{16}$ will help to describe the clinical impact method. First, the patients were asked to spontaneously point out all the physical, emotional, and social problems resulting from their pulmonary disease. When the spontaneous items were completed, they were shown a previously elaborated list and asked which of the items listed represented problems in their lives (stimulated answers). Following this, the patients were asked to rate the importance of each identified item (spontaneous and stimulated) on 5-point Likert scale, varying from "not very important" to "very important." To determine the most important items, the number of patients that labeled a particular item as a problem (frequency) was multiplied by the mean importance attributed to that item (importance). The product of frequency and importance represented the significance of each item in the patients' lives 
(impact), which was represented numerically by a score. The items were ranked according to their impact score, which ensured the discrimination of those with more significance for the quality of life.

\section{Item generation}

Once the conceptual framework and the construction methodology are chosen, it is necessary to identify the relevant items for the construct to elaborate the item pool that is going to be administered to the target population for their evaluation of it. The items must be generated from all possible sources: interviewing elderly patients, reviewing of the literature (clinical studies and other questionnaires), drawing on personal clinical experience in developing the object of study, and consulting with experts. A comprehensive pool of items is then generated, where the selected items are used to measure the attributes. This pool must be checked to verify that there is appropriate representation of all pertinent aspects.

The generated items of our study were drawn from 3 sources: review of the answers of a specific interview given to the elderly ${ }^{11-13}$; review of other instruments found in the literature, especially those constructed for the elderly population $^{23}$; and our clinical experience with elderly patients.

The principal source was the interviews with 86 elderly patients from the Group of Multidisciplinary Attendance to the Elderly (Grupo de Atendimento Multidisciplinar ao Idoso Ambulatorial - GAMIA) of the Geriatric Service of Hospital das Clínicas da Faculdade de Medicina da Universidade de São Paulo (SGHC-FMUSP) between the years 1996 and 1998. Each patient was asked about the factors that determine good and bad quality of life in the old age, their fears, and their desires by the principal author exclusively. They were also asked to rank 3 factors that are essential for a good quality of life and 3 for a bad quality of life in the old age, according to their importance. In order to identify the quality of life determinants, 2 questions were asked: "If you could, what would you put into your life to make it better?" and "If you could, what would you take out of your life to make it better?" Then they were questioned about their greatest fear and their desires using the Aladdin's magic lamp tale.

\section{Methodology adaptation and item pool appropriation}

In order to delineate the procedures and to adjust the methodology, a pilot study was conducted, where 19 elderly patients of the Geriatric Ambulatory of SGHC-FMUSP were interviewed by the principal author exclusively, from December 1999 to March 2000. The interviews generated an item pool and procedures to be used in later stages (item reduction and dimension identification). ${ }^{7}$ Therefore, the appropriateness of the methodology adaptation and of item pool were assessed.

This adaptation was necessary because quality of life is not a disease where a patient can indicate "the problems due to his/her quality of life." So, items that are relevant to quality of life must be identified in the item pool, ie, the ones that affected the patients positively (they make their quality of life better) as well as negatively (they make their quality of life worse). Therefore, the first adaptation made was to look for relevant items, those that influence the quality of life positively as well as negatively, instead of looking for troublesome items as for a disease. For a disease, items that affect life in a negative way (problems) are elected; whereas for quality of life, the items that affect it bipolarly are chosen (relevance). The items that the elderly evaluated as not affecting their lives at all were discarded.

A second adaptation was done regarding the importance ascribed to each item. The elderly were asked to rate the importance of each relevant item for a good or bad quality of life in the old age, depending on how this item was initially classified, as a determinant of good or bad quality of life, respectively, on a 5-point Likert scale going from "not important" to "extremely important." This was done using the following questions: "What is the importance of item $\mathrm{x}$ for a good quality of life in the old age?" for items the patient considered relevant for a good quality of life in the old age, and "What is the importance of item y for a bad quality of life in the old age?" for items the patient considered relevant for a bad quality of life in the old age. Due to the difficulty the elderly had in understanding these two questions, a shortened and more direct form was tested: "How much does item $\mathrm{x}$ improve the quality of life in the elderly?" (for items previously evaluated as determinant of a good quality of life in old age) and "How much does item y worsen the quality of life of the elderly?" (for items previously evaluated as determinant of a bad quality of life in old age) .?

Another objective of the pilot study was to identify items or words poorly understood or ambiguous or that elicited hostile or undesirable answers and to verify that all elderly patients would interpret the questions the same way or whether there are unwanted answers or answers that would not be given, according to the recommendations of Armstrong et al. ${ }^{24}$

\section{RESULTS}

\section{Item generation}

The analysis of the 86 questionnaires applied in the GAMIA (1996-1998) allowed us to catalog 1032 answers, 
which were combined initially by similarity (e.g., own house, beach house, big/small apartment, nice/not so nice house); answers were then grouped into 3 major categories: health, psychosocial, and economic aspects (Table 2). After a more detailed analysis, they were grouped into 8 categories (Table 3). The answers given by the patients represented the items, distributed into these categories. Then, in the item selection stage, items that were either redundant or poorly written were eliminated, resulting in a total of 138 items that all related to the quality of life in the elderly.

Table 2 - Examples of items grouped into 3 big categories

\begin{tabular}{|c|c|}
\hline CATEGORIES & ITEMS \\
\hline HEALTH & $\begin{array}{l}\text { Mental and physical health } \\
\text { Good memory } \\
\text { Not depending physically on anyone }\end{array}$ \\
\hline PSYCHOSOCIAL ASPECTS & $\begin{array}{l}\text { Good friendships } \\
\text { Care and attention from the family } \\
\text { Peace and tranquility } \\
\text { Loneliness } \\
\text { Faith in God } \\
\text { Complaining about life } \\
\text { Respected by the community }\end{array}$ \\
\hline ECONOMIC ASPECTS & $\begin{array}{l}\text { Lack of money } \\
\text { Good retirement } \\
\text { Place to live } \\
\text { Having enough to live on }\end{array}$ \\
\hline
\end{tabular}

Table 3 - Categories found in the item generation stage

Physical Health

Autonomy / Independence / Functional Capacity

Social Aspects

Family

Economic Aspects

Psychologic Aspects

Religion / Transcendence

Environment

\section{Appropriateness of methodology adaptation and item pool.}

The pilot study (1999-2000) demonstrated the feasibility of the application of the Clinical Impact Method and the possibility of identifying the most important items for the quality of life in old age from a previously elaborated list. The pilot study was useful for delineating the correct manner in which to ask about the influence (good or bad) of each item in the quality of life (stimulated stage) and to verify its importance to the construct, thus allowing the evaluation of the appropriateness of the methodology. It was then possible to apply this technique to construct a measuring instrument for the quality of life in the elderly.
The pilot study fulfilled its purpose, serving to evaluate the preliminary item pool and the methodology and serving also as training tool for the investigator. The initial 138 -item pool was modified to a final 139 -item pool (Table 4), which is the result of the deletion of 1 redundant item ("sleeping without medicine") and the inclusion of 2 new ones, suggested spontaneously by the elderly participants of the pilot study ("bad friendships; bad influences" and "sleeping outside of the scheduled time; not having a predetermined time to sleep"). Furthermore, 20 poorly understood items were rewritten (eg, "inactivity" for "having nothing to do"). The way of asking the questions and how the interview is done were also modified. Clearly, an appointment for the interviews is necessary to ensure data quality. Also, the difficulty the elderly participants had in understanding the Likert scale rating, especially the intermediate values, revealed the need to rewrite the ratings, while maintaining the 5-point scale. Therefore, the final answer options were as follows: $1=$ almost nothing; $2=\mathrm{a}$ little; $3=$ moderately; $4=$ a lot; and $5=$ extremely. This was the final form of the Likert scale, and the elderly participants did not have any problems understanding it. ${ }^{\text {? }}$

\section{DISCUSSION}

The concept that quality of life is the difference between what is idealized and what is accomplished has been already described. In 1984, Calman ${ }^{25}$ introduced the idea of using the one's own expectations as a standard to compare one's quality of life. Thus, one way of understanding quality of life is to estimate the difference between people's expectations and their accomplishments. Our conception is also close to the concept of need satisfaction of Liss, ${ }^{26}$ especially in the sense that "need is an instrument for reaching objectives."

In addition to Calman, several other authors have written about the same theoretical-conceptual framework, with different definitions of quality of life. The following definitions for quality of life were found ${ }^{27}$ : "Quality of life is the extent a person achieves his or her life objectives" (Cella; Cherin, 1987); "Quality of Life is expressed in terms of the distance between a person's position and his or her objectives. The satisfaction is related to the conquest of an objective or the sensation of its approximation" (Sartorius, 1987). These are definitions used the framework we used in our model years later.

According to Fayers and Machin, ${ }^{28}$ "Calman's expectation model suggests that people have objectives and goals and that quality of life is the measure of the difference between one's hopes and expectations and his actual experience." This difference can be decreased by enhancing the 
Table 4 - 139-item pool to be used in the item-reduction stage

1. Having friendships

2. Living without significant pain

3. Taking medicine

4. Being able to take care of yourself (bathing, dressing, feeding yourself, etc.)

5. Experiencing loneliness

6. Owning a house

7. Living in peace with the family

8. Going to clubs, associations, churches, groups

9. Having health

10. Lacking money

11. Being able to read and write

12. Being able to love

13. Having nothing to do

14. Being understood by younger people

15. Relying on others for daily activities

16. Walking without difficulty for 30 minutes

17. Liking yourself; being happy with yourself (self-esteem)

18. Having a reason to live

19. Practicing physical activity (sports, walking, jogging, etc)

20. Having good nourishment; healthy food

21. Complaining about life

22. Experiencing peace/tranquility

23. Having the ability to decide, to lead

24. Being abandoned by the family

25. Being respected by society

26. Going to movies, theater, concerts, outings, etc

27. Using public transportation (bus, subway, etc)

28. Living with other people, but feeling lonely

29. Having children who are well-off

30. Dating

31. Having a good retirement pension

32. Having lack of hygiene

33. Felling well, full of energy

34. Being physically independent

35. Visiting the family or having the family visit frequently

36. Visiting friends and neighbors or having them visit frequently

37. Not believing in God

38. Peaceful life, without worries

39. Having peaceful sleep

40. Experiencing sexual activity; having sexual intercourse

41. Health-related problems

42. Feeling respected by society

43. Having peace of mind

44. Accepting your own age, coming to terms with your own age

45. Having a spouse, a partner

46. Being in poverty

47. Having a meaning for your own life

48. Having freedom

49. Having a disability in the senses (vision, hearing, smell, taste etc.)

50. Adjusting to losses; knowing how to loose

51. Having enough to live

52. Having enough earnings to cover the expenses

53. Having more earnings than expenses

54. Living alone

55. Having control over your own life

56. Experiencing grumpiness, crankiness; bad mood

57. Having division in the family

58. Knowing how to live and interact with other people

59. Continuing to be active in your own environment (to make calls, to shop, to be in change of the finances, etc)

60. Doing household chores (cooking, washing, cleaning, tiding the house, fixing things etc.)

61. Traveling

62. Liking what you do

63. Doing what you like

64. Needing to diet
65. Stable financial situation

66. Having the disposition to work

67. Having faith in God

68. Experiencing joy; happiness

69. Having addictions (alcohol, smoking, gambling, drugs, etc)

70. Continuing to practice your own profession

71. Having an elementary school diploma

72. Developing new skills and abilities

73. Lacking respect in the society

74. Being able to choose the TV or radio program to be watched

75. Having public safety

76. Fulfilling the basic needs (food, dressing, living, transportation, health, recreation, etc)

77. Trusting in the future

78. Doing good for others; feeling of solidarity

79. Feeling accomplished; having achievements

80. Lacking friends, companionship

81. Being promptly served in any health service when needed

82. Having illness

83. Having low purchase power; low income

84. Liking your own body

85. Feeling useful

86. Experiencing violence (assault, robbery, fight, etc)

87. Being remembered by your children

88. Being able to keep working

89. Having patience

90. Having memory loss; forgetfulness

91. Being able to sleep easily

92. Being able to drive

93. Having bad friendships; bad influences

94. Having a confident; being able to talk to someone

95. Adjusting to the world changes (technology, ATM, telephone, cell phone, computers, fashion, music, morals, etc)

96. Having family harmony

97. Going to parties, weddings, gatherings

98. Having plans and projects for the future

99. Having family support

100. Having friends' support

101. Being well with one's self

102. Needing medical assistance

103. Receiving financial aid from the children

104. Being loved

105. Having a religion

106. Having an ideal to follow

107. Controling your weight

108. Lacking a place to live

109. Feeling healthy

110. Getting along with the neighbors

111. Having ease of transportation

112. Unhealthy eating habits

113. Having a job

114. Learning new things

115. Taking care of the grandchildren

116. Being liked by others

117. Living with relatives (children, in-laws, grandchildren, etc)

118. Participating in movements, associations, unions, councils, etc

119. Having peace and tranquility

120. Unpolluted environment

121. Feeling a burden to others

122. Having a low salt diet

123. Arguing with the family

124. Knowing that the children are well

125. Having fun, recreation and filling in free time

126. Living well (running water and sewage systems, comfort, security, etc)

127. Having a chronicle disease (diabetes mellitus, high blood pressure, arthritis etc.) 
Table 4 - cont.

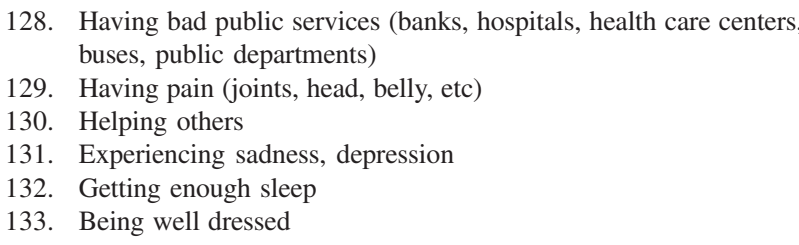

patient's functionality or by modifying his or her expectations. Two instruments that use Calman's expectation model as their conceptual framework, allowing the inclusion of personal values, are the Schedule for Evaluation of Individual Quality of Life-SEIQoL (O'Boyle et al, 1993) and the Patient Generated Index-PGI (Ruta et al, 1994). ${ }^{28}$

Like Calman, we compared the subject's idealized standard at a single point in time to his or her actual quality of life, estimating the difference between his or her expectations and the actual achievements. If the subject changes his way of thinking and looking at life, changing his evaluation of quality of life, each item would be valued differently because of changes in his or her life situations (he or she is accomplishing more or achieving less than he or she used to); therefore, the standard would change with time, but this comparison would always be possible. This is an important property, because one of the characteristics of the quality of life construct is its mutability, varying according to the person, place, point in time, state of mind, and humor.

The clinical impact method was chosen because of its feasibility and practicality. This method allows an easier construction of the instrument using all 139 items we generated in the item-generation stage and requires a smaller
134. Being elegan

135. Needing medicine

136. Feeling lonely

137. Being dependent in general (physical, economic, social, etc)

138. Enjoying every moment in life

139. Sleeping outside of the scheduled time; not having a predetermined time to sleep sampling size (number of interviews). Factor analysis indicates that a sample of at least 690 elderly subjects would be required. The instruments using the clinical impact method were constructed with much smaller samples, even if the number of items was large, such as in the Inflammatory Bowel Disease Questionnaire-IBDQ,${ }^{17}$ where a 150 item scale was applied to 97 patients with inflammatory intestinal diseases (Crohn disease and ulcerative colitis), and in the Geriatric Quality of Life Questionnaire ${ }^{21}$, where a 131-item questionnaire was administered to 100 elderly subjects with functional impairments. Moreover, this technique was also chosen because of the large number of published studies using instruments constructed with this method, demonstrating its applicability.

Thus, the theoretical-conceptual framework of the construct was established, the construction methodology was chosen, and the items were generated. Not only was the methodology adapted, but the item pool was also determined, both of them through the pilot study. The next step must be the items-reduction process. With this process, we intend to narrow our item pool, arriving at the items with the greatest impact in elderly life and to send them to experts for grouping into dimensions that are relevant for the quality of life in old age.

\section{RESUMO}

Paschoal SMP, Jacob Filho W, Litvoc J. Desenvolvimento do Índice de Qualidade de Vida do Idoso - IQVI: Base teórico-conceitual, metodologia escolhida e geração de itens relevantes. Clinics. 2007;62(3):279-88.
OBJETIVO: Descrever os passos iniciais do processo de construção de um instrumento de avaliação de qualidade de vida de idosos: a base teórico-conceitual do constructo Qualidade de Vida na Velhice, a metodologia escolhida 
para a construção e a geração dos itens relevantes.

MÉTODOS: O primeiro passo foi conceituar e definir o constructo, evidenciando o quanto os idosos realizam do que consideram importante para suas vidas e se estão satisfeitos com o que foi possível concretizar. O segundo, escolher e descrever a metodologia de construção (Método do Impacto Clínico) e a fase de geração de itens relevantes ao objeto de estudo. Através de estudo piloto, foram delineados os procedimentos necessários, estabelecendo-se todas as fases da metodologia. Demonstrou-se a viabilidade de seu emprego na construção de um instrumento de avaliação de qualidade de vida de idosos, com as adaptações necessárias.
RESULTADOS: A geração de itens selecionou, de 1032 respostas de idosos, 138 itens relevantes ao constructo. $\mathrm{O}$ estudo-piloto mostrou a viabilidade de aplicação da metodologia e estabeleceu modificações na lista preliminar de itens, resultando nova lista (139 itens).

DISCUSSÃO: Estabelecida a base teórico-conceitual do constructo e a metodologia de construção, selecionados os itens e realizado o piloto, a etapa seguinte consistirá em submeter a lista a uma amostra de idosos, para redução dos itens e distribuição em dimensões.

UNITERMOS: Idoso, Qualidade de Vida, Questionários, Avaliação, Impactos na Saúde.

\section{REFERENCES}

1. McSweeny AJ, Creer TL. Health-related quality of life assessment in medical care. Dis Mon. 1995;XLI:12-15.

2. Lapierre S, Bouffard L, Bastin E. Personal goals and subjective wellbeing in later life. Int J Aging Hum Dev. 1997;45:287-303.

3. Xavier FMF, Ferraz MPT, Marc N, Escosteguy NU, Moriguchi EH Elderly people's definition of quality of life. Rev Bras Psiquiatr. 2003;25:31-9.

4. Fleck MPA, Chachamovich E, Trentini CM. Projeto WHOQOL-OLD: método e resultados de grupos focais no Brasil. Rev Saúde Publ. 2003;37:793-9.

5. Johnston MV, Micklos CS. Activity-related Quality of Life in rehabilitation and traumatic brain injury. Arch Phys Med Rehabil. 2002;83 Suppl 2: S26-S38.
6. Paschoal SMP. Qualidade de Vida do Idoso: construção de um instrumento de avaliação através do método do impacto clínico [tese]. São Paulo: Faculdade de Medicina, Universidade de São Paulo; 2004.

7. Paschoal SMP. Qualidade de Vida do Idoso: Elaboração de um instrumento que privilegia sua opinião [dissertação]. São Paulo: Faculdade de Medicina, Universidade de São Paulo; 2000.

8. Cornejo Arias E, Kirschbaum Kasten A, Castillo P. Problemas de salud de los senescentes em Chile. Bol Hosp Viña del Mar. 1987;43:157-64.

9. Marx RG, Bombardier C, Hogg-Johnson S, Wright JG. Clinimetric and Psychometric Strategies for Development of a Health Measurement Scale. J Clin Epidemiol. 1999;52:105-11.

10. Wright JG, Feinstein AR. A comparative contrast of clinimetric and psychometric methods for constructing indexes and rating scales. J Clin Epidemiol. 1992;45:1201-18. 
11. Litvoc J, Pereira JCR, Paschoal SMP, Jacob-Filho W. Qualidade de vida dos idosos: avaliação dos parâmetros objetivos (tema livre $\mathrm{n}^{\circ} 069$ apresentado ao I Congresso de Geriatria e Gerontologia do Mercosul; 1999 Maio 12-15; Foz do Iguaçu, Brasil, Anais).

12. Paschoal SMP, Litvoc J, Jacob-Filho W. Qualidade de vida dos idosos: avaliação dos parâmetros subjetivos (tema livre $\mathrm{n}^{\circ} 070$ apresentado ao I Congresso de Geriatria e Gerontologia do Mercosul; 1999 Maio 1215; Foz do Iguaçu, Brasil, Anais).

13. Jacob-Filho W, Paschoal SMP, Litvoc J. Qualidade de vida dos idosos: apresentação de um instrumento (tema livre $\mathrm{n}^{\circ} 071$ apresentado ao I Congresso de Geriatria e Gerontologia do Mercosul; 1999 Maio 12-15; Foz do Iguaçu, Brasil, Anais).

14. Kirshner B, Guyatt GH. A methodological framework for assessing health indices. J Chronic Dis. 1985;38:27-36.

15. Guyatt GH, Bombardier C, Tugwell PX. Measuring disease specific quality of life in clinical trials. CMAJ. 1986;134:889-95.

16. Guyatt GH, Townsend M, Berman LB, Pugsley SO. Quality of Life in patients with chronic airflow limitation. Br J Dis Chest. 1987;81: 4554.

17. Guyatt GH, Mitchell A, Irvine EJ, Singer J, Williams N, Goodacre R et al. A new measure of health status for clinical trials in inflammatory bowel disease. Gastroenterology. 1989;96:804-10.

18. Juniper EF, Guyatt GH, Epstein RS, Ferrie PJ, Jaeschke R, Hiller TK. Evaluation of impairment of health related quality of life in asthma: development of a questionnaire for use in clinical trials. Thorax. 1992;47:76-83.

19. Juniper EF, Guyatt GH, Streiner DL, King DR. Clinical Impact Versus Factor Analysis for Quality of Life Questionnaire Construction. J Clin Epidemiol. 1997;50:233-8.
20. Mitchell A, Guyatt G, Singer J, Irvine EJ, Goodacre R, Tompkins C et al. Quality of Life in patients with inflammatory bowel disease. J Clin Gastroenterol. 1988;10:306-10.

21. Guyatt GH, Eagle J, Sackett B, Willan A, Griffith L, Mcilroy W et al. Measuring quality of life in the frail elderly. J Clin Epidemiol. 1993;46:1433-44.

22. Cook DJ, Guyatt GH, Adachi JD, Clifton J, Griffith LE, Epstein RS et al. Quality of life issues in women with vertebral fractures due to osteoporosis. Arthritis Rheum. 1993;36:750-6.

23. McDowell I, Newell C. Measuring Health. A guide to rating scales and questionnaires. 2ed. New York, Oxford: Oxford University Press; 1996.

24. Armstrong BK, White E, Saracci R. The design of questionnaires. In: Armstrong BK, White E, Saracci R, editors. Principles of Exposure Measurement in Epidemiology. Oxford: Oxford University Press; 1992. p.137-70.

25. Calman KC. Quality of life in cancer patients—an hypothesis. J Med Ethics. 1984;10:124-7.

26. Liss P. On need and quality of life. In: Nordenfelt L, editor. Concepts and measurement of quality of life in health care. Dordrecht: Kluwer Academic Publishers; 1994. p. 63-78.

27. Farquhar M. Definitions of quality of life: a taxonomy. J Adv Nurs 1995;22:502-8.

28. Fayers PM, Machin D. Introduction. In: Fayers PM, Machin D, editors. Quality of Life. Assessment, Analysis and Interpretation. Chichester: John Wiley \& Sons LTD; 2000. p. 3-27. 